\title{
COMPOSITION OF CARCASS SIDES AND QUALITY OF MEAT FROM SWALLOW-BELLY MANGALITSA REARED IN TWO SYSTEMS
}

\author{
M. Petrović ${ }^{1}$, Č. Radović ${ }^{2}$, N. Parunović ${ }^{3}$, D. Radojković ${ }^{1}$, R. Savić ${ }^{4}$ \\ ${ }^{1}$ Faculty of Agriculture, University of Belgrade, 11080, Belgrade - Zemun, Repulic of Serbia \\ ${ }^{2}$ Institute for Animal Husbandry, 11080, Belgrade-Zemun, Repulic of Serbia \\ ${ }^{3}$ Institute of Meat Hygiene and Technology, 11000, Belgrade, Repulic of Serbia \\ ${ }^{4}$ A.D. Doža Djerdj, 24300, Bačka Topola, Republic of Serbia \\ *Corresponding author, e-mail: milica@agrif.bg.ac.rs \\ Original scientific paper
}

\begin{abstract}
Objective of this paper was to determine the composition of carcass sides and quality of meat obtained from two groups of fatteners (male castrated pigs) of Swallow-Belly Mangalitsa breed. First group was reared in an open system $(\mathrm{SO}, \mathrm{n}=13)$ and the other group in farm conditions with free ranges $(\mathrm{SI}, \mathrm{n}=10)$. Animals were slaughtered in the same slaughtering facility. Left carcass sides were dissected and percentage of meat (Actual LMP) calculated according to EU reference method (EC, No 1249/2008). Data obtained in the study was analyzed using GLM procedure of the program package SAS 9.1.3 (SAS Inst.Inc., 2002-2003).Average pre slaughter body weight of fatteners was $103.83 \pm 10.13 \mathrm{~kg}$. Housing and nutrition system in production of fatteners had statistically highly significant effect $(p<.0001)$ on pre-slaughter age of fatteners. Statistically significant differences were obtained only in mean values obtained for back fat measured on single location/position - lower back (BFR I) between fatteners of groups SO and SI. Total weight of all individual carcass side parts and weight of relevant muscle tissue, depended on the weight of warm carcass sides (WHC) but not on the housing system (SBF). Carcass sides of fatteners contained in average $35.64 \pm 4.39 \%$ of muscle tissue (Actual LMP). Meat content in carcass sides (Predicted LMP) was determined according to Rulebook/Pravilnik (1985) for fatty pig breeds and it was $29.67 \pm 1.27 \%$. In the musculus longissimus dorsi (MLD) of fatteners reared in closed system, was recorded higher content of water $(p=0.0069)$, lower content of total fats/lipids $(p=0.0081)$ and higher content of ash $(p=0.0392)$ compared to animals from the open system of housing. No statistically significant differences in average protein content $(p=0.5940)$ and $\mathrm{pH}_{1}$ value $(p=0.0659)$ were established between fatteners reared in open and closed system of housing.
\end{abstract}

Key words: pig, Mangalitsa, housing system, carcass sides, meat quality 


\section{Introduction}

In recent years, the interest of researchers for traits of local pig breeds and their rearing in extensive conditions increased (Butko et al., 2007; Parunović et al., 2012; Petrović et al., 2009; 2010 and 2011; Pugliese et al., 2003 and others).

Mangalitsa is typical fatty pig breed with 28 to $35 \%$ of meat in carcass sides (Egerszegi et al., 2003; Kralik and Petričević,2001, Petrović et al.,2009;2010 and 2011). Swallow-Belly Mangalitsa originates from the region of Srem (vicinity of Ruma, village Buđanovci). Because of exceptionally modest requirements and resistance it was very popular in Vojvodina (especially in Srem) and Hungary in the period from mid XIX to mid XX century. There was a demand not only for meat but also for fat and bacon on the European market then. Today, Mangalitsa is reared within an organized system in several herds in Republic of Serbia and is the most numerous indigenous/autochthonous pig breed. The quality of meat coming from Mangalitsa pigs is exceptional due to lower content of saturated fatty acids, compared to other pig breeds (Holló et al.,2003 and Parunović et al., 2012). Housing system, in addition to other factors, influences the content of intramuscular and inter-muscular fat, muscle tissue, water, proteins and lipids, as established by certain researchers (Pugliese et al., 2005; Butko et al., 2007; Parunović et al., 2012 and others). Today, indigenous/autochthonous pig breeds are reared in open system or farm conditions and fed the traditional way or using complete mixtures.

Objective of this paper was to establish the carcass side composition and quality of meat of Swallow-Belly Mangalitsa fatteners reared in two housing and nutrition systems.

\section{Material and Methods}

The study included 23 Swallow-Belly Mangalitsa fatteners (male castrated pigs) reared in two housing systems (open and closed). The first group (SO, $n=13$ ) was reared in the open system in the woods and grazed, fed roots and other fruits with addition of small quantity of corn (to $0,3 \mathrm{~kg} / \mathrm{animal} / \mathrm{day}$ ). During night and poor weather conditions animals were kept in a wooden facility. The second group (SI, $n=10$ ) was reared in farm conditions with free ranges. Area of the open range was $110 \mathrm{~m}^{2}$ and overhanged space was $40 \mathrm{~m}^{2}$. There were 10 animals in each group which means that area of $1,5 \mathrm{~m}^{2}$ was provided per animal. During fattening animals were fed two complete mixtures consisting of corn silage, livestock meal, soy bean meal, sunflower meal, synthetic lysine, mineral additives and premix. First mixture contained in average $15 \%$ and the other $13 \%$ of crude proteins. Water was ad libitum. Animals were slaughtered in the same slaughtering facility. Linear measures of warm carcass sides were taken on the slaughter line and $\mathrm{pH}$ value of 
musculus longissimus dorsi (MLD) measured in the first hour subsequent to slaughtering. Yield of meat was determined on left carcass sides by method of partial dissection (Walstra and Merkus, 1996) and calculation of the percentage of meat were done according to EU reference method (EC, No.1249/2008, Actual LMP). The percentage of meat according to the Rulebook (1985; for fat pigs) (Predicted LMP) was estimated as the sum of the two measured fat thickness (the first measure: mid-back between the 13th and 15th vertebrae, the second measure: on rump above musculus gluteus medius where it grows into fat tissue the most) and warm carcass weight. Protein content, water, total fats and ashes were determined by Association of Official Analytical Chemists (AOAC, 1990).

Obtained data was processed using procedure GLM of the program package SAS 9.1.3 (SAS Inst.Inc., 2002-2003). Into fully random model housing system and pre-slaughter body weight or warm carcass side weight was included.

\section{Results and Discussion}

Average pre-slaughter body weight of fatteners was $103.83 \pm 10.13 \mathrm{~kg}$ (Table 1). Warm and cooled carcass sides had in average $82.31 \pm 9.01$ and $80.22 \pm$ 9.02 kilograms, respectively. The thickest bacon was measured at withers (BFW, $61.74 \pm 9.70 \mathrm{~mm}$ ) and the thinnest in the middle of the back (BFC, $42.74 \pm 7.39$ $\mathrm{mm})$. The variation range of $\mathrm{BFW}$ and $\mathrm{BFC}$ was from 48.00 to 85.00 and from 27.00 to 55.00 millimetres, respectively.

Table 1. Average values and variability of linear measures of Swallow-Belly Mangalitsa carcass sides

\begin{tabular}{|l|r|r|r|r|}
\hline Trait & \multicolumn{1}{|c|}{$\bar{x}$} & \multicolumn{1}{c|}{ SD } & \multicolumn{1}{c|}{ Min. } & \multicolumn{1}{c|}{ Max. } \\
\hline Pre-slaughter body weight (BWS), kg & 103.83 & 10.13 & 90.00 & 127.00 \\
\hline Warm carcass side weight (WWC), kg & 82.31 & 9.01 & 71.00 & 104.00 \\
\hline Cold carcass side weight (WCC), kg & 80.22 & 9.02 & 68.90 & 102.00 \\
\hline Fat thickness at withers (BFW), mm & 61.74 & 9.70 & 48.00 & 85.00 \\
\hline Fat thickness in the middle of the back, between 13 ${ }^{\text {th }}$ and & 42.74 & 7.39 & 27.00 & 55.00 \\
$1^{\text {th }}$ vertebrae (BFC), mm & & & & \\
\hline Fat thickness at lower back: & & & & \\
- where musculus gluteus starts (BFR I), mm & 53.70 & 10.32 & 38.00 & 70.00 \\
- where musculus gluteus grows into the fat (BFR II), & 47.83 & 8.65 & 35.00 & 63.00 \\
mm & 53.70 & 9.80 & 35.00 & 76.00 \\
\hline - where musculus gluteus ends (BFR III), mm & 92.78 & 4.32 & 87.00 & 101.00 \\
\hline Length Os pubis-atlas (OP-A), cm & 76.26 & 3.38 & 71.00 & 82.50 \\
\hline Length Os pubis-1. rib (OP-1.R), cm & & & & \\
\hline
\end{tabular}

Statistically significant differences were established in mean values only for fat thickness measured on single position in lower back (BFR I) between fatteners SO and SI (Table 2). All linear measures on warm carcass sides, except 
for BFR II and BFR III, depended on weight of warm carcass sides and preslaughter weight of fatteners.

Table 2. The influence of housing and nutrition system (SBF) and warm carcass side weight (WWC) on varying of linear carcass side measures

\begin{tabular}{|l|c|c|c|c|c|}
\hline \multirow{2}{*}{ Trait ${ }^{1)}$} & \multicolumn{2}{|c|}{$\mathrm{SBF}^{2)}(\mathrm{LS} \mathrm{Mean} \pm \mathrm{SE})$} & $\mathrm{SBF}$ & WWC (b) & \multirow{2}{*}{$\mathrm{R}^{2}$} \\
\cline { 2 - 6 } & Open (SO) & Closed (SI) & p -value & p -value & \\
\hline BFW, mm & $63.78 \pm 2.00$ & $59.09 \pm 2.28$ & 0.1391 & 0.0006 & 0.497 \\
\hline BFC, mm & $43.67 \pm 1.73$ & $41.53 \pm 1.97$ & 0.4249 & 0.0051 & 0.354 \\
\hline BFR I, mm & $57.20 \pm 2.18^{\mathrm{A}}$ & $49.13 \pm 2.49^{\mathrm{B}}$ & 0.0245 & 0.0038 & 0.472 \\
BFR II, mm & $50.24 \pm 2.26$ & $44.69 \pm 2.58$ & 0.1217 & 0.1775 & 0.197 \\
BFR III, mm & $56.26 \pm 2.50$ & $50.37 \pm 2.86$ & 0.1375 & 0.0932 & 0.228 \\
\hline OP-A, cm & $92.36 \pm 1.05$ & $93.78 \pm 1.20$ & 0.3837 & 0.0099 & 0.301 \\
\hline OP-1.R, cm & $75.61 \pm 0.78$ & $77.11 \pm 0.89$ & 0.2199 & 0.0034 & 0.377 \\
\hline
\end{tabular}

1) Traits: explained in Table $1 ;{ }^{2} \mathrm{SBF}$ - system of housing and nutrition; ${ }^{3)} \mathrm{WWC}(\mathrm{b})$ - weight of warm carcass sides (regression effect); A, B - significance at the level of $\mathrm{p}<0.05$;

Obtained results in our researches show that animals reared in open system have statistically significantly thicker fat measured at lower back (BFR I, +8.07 $\mathrm{mm}$ ) compared to animals from closed system. Contrary to this, Butko et al. (2007) and Pugliese et al. (2003) have established thinner back fat in fatteners belonging to local breeds reared in open system. In our researches, only male castrated animals of Swallow-Belly Mangalitsa (fatty breed) were fattened and reared in closed system, fed mixtures which contained more protein compared to the study carried out on Black Slavonian breed (breed of combined production capacity) reported by Butko et al. (2007).

Total weight (TM) of all four individual carcass side parts and weight of muscle tissue (MT) in them, depended on the weight of hot carcass sides, but not on housing system (Table 3). Male castrated animals reared in closed system were younger at slaughtering and had lower average leg weight compared to animals from open system of housing, but the difference established wasn't statistically significant $(p=0.0896)$. Of total ham weight, muscle tissue content was 45.58 (open system) and $48.32 \%$ (closed system). Similar share of muscle tissue was established in shoulder (47.90 and 45.67\%). Percentage of muscle tissue in backloin and belly-rib carcass side parts in fatteners reared in closed system was higher (28.87 and $28.06 \%$ ) compared to fatteners from closed system (25.59 and $25.12 \%)$, but differences weren't statistically significant $(\mathrm{p}>0.05)$. 
Table 3. Statistical significance of influences (factors) included in the model (SBF and WWC) for analysis of total weight (TM, kg), weight of muscle tissue (MT, $\mathrm{kg}$ ) and content of muscle tissue (LMP, \%) in four major carcass side parts of Swallow-Belly Mangalitsa

\begin{tabular}{|c|c|c|c|c|c|c|}
\hline \multirow{2}{*}{\multicolumn{2}{|c|}{ Carcass side part }} & \multicolumn{2}{|c|}{$\mathrm{SBF}^{1)}(\mathrm{LS}$ Mean $\pm \mathrm{SE})$} & \multirow{2}{*}{$\frac{\mathrm{SBF}}{\mathrm{p} \text {-value }}$} & \multirow{2}{*}{$\frac{\text { WHC }^{2)}}{\mathrm{p} \text {-value }}$} & \multirow[t]{2}{*}{$\mathrm{R}^{2}$} \\
\hline & & Open (SO) & Closed (SI) & & & \\
\hline \multirow[t]{3}{*}{ Ham } & TM & $8.253 \pm 0.158$ & $7.825 \pm 0.180$ & 0.0896 & $<.0001$ & 0.751 \\
\hline & MT & $3.749 \pm 0.093$ & $3.753 \pm 0.106$ & 0.9741 & $<.0001$ & 0.609 \\
\hline & LMP & $45.58 \pm 1.30$ & $48.32 \pm 1.48$ & 0.1792 & 0.7756 & 0.094 \\
\hline \multirow[t]{3}{*}{ Back-loin } & TM & $6.515 \pm 0.213$ & $6.620 \pm 0.243$ & 0.7513 & 0.0048 & 0.313 \\
\hline & MT & $1.764 \pm 0.101$ & $1.907 \pm 0.115$ & 0.3590 & 0.0319 & 0.204 \\
\hline & LMP & $25.59 \pm 1.07$ & $28.87 \pm 1.22$ & 0.0563 & 0.8048 & 0.170 \\
\hline \multirow[t]{3}{*}{ Shoulder } & TM & $4.453 \pm 0.126$ & $4.815 \pm 0.144$ & 0.0742 & $<.0001$ & 0.620 \\
\hline & MT & $2.132 \pm 0.076$ & $2.186 \pm 0.086$ & 0.6403 & 0.0034 & 0.357 \\
\hline & LMP & $47.90 \pm 1.07$ & $45.67 \pm 1.22$ & 0.1872 & 0.2000 & 0.145 \\
\hline \multirow[t]{3}{*}{ Belly-rib } & TM & $4.596 \pm 0.151$ & $4.378 \pm 0.172$ & 0.3517 & $<.0001$ & 0.632 \\
\hline & MT & $1.143 \pm 0.075$ & $1.204 \pm 0.086$ & 0.6016 & 0.0303 & 0.218 \\
\hline & LMP & $25.12 \pm 1.92$ & $28.06 \pm 2.18$ & 0.3240 & 0.6281 & 0.063 \\
\hline \multicolumn{2}{|c|}{$\begin{array}{l}\text { Predicted LMP } \\
\text { (Rulebook,1985) }\end{array}$} & $29.26 \pm 0.34$ & $30.19 \pm 0.38$ & 0.0858 & 0.1957 & 0.213 \\
\hline \multicolumn{2}{|c|}{$\begin{array}{l}\text { Actual LMP (EC, No } \\
1249 / 08)\end{array}$} & $34.54 \pm 1.22$ & $37.07 \pm 1.39$ & 0.1875 & 0.6961 & 0.095 \\
\hline
\end{tabular}

${ }^{1)} \mathrm{SBF}$ - housing system and nutrition; ${ }^{2)} \mathrm{WWC}(\mathrm{b})$ - weight of warm carcass sides (regression effect);

Fatteners reared in the closed system has by $2.53 \%$ more muscle tissue in carcass sides (mean value 37.07\%) than fatteners from open system (mean value $34.54 \%)$, however, established difference wasn't statistically significant $(\mathrm{p}=0.1875)$.

Housing system and nutrition influence the quantity and percentage of muscle and fat tissue in carcass sides of Black Slavonian pig (Butko et al.,2007). Animals reared in closed system had less muscle tissue (38.50\%) in carcass sides than animals reared in open system $(41.0 \%)$. In present research, no statistically significant differences were established in content of muscle tissue (Actual LMP) between fatteners reared in open and closed system (34.54 and 37.07\%, respectively). Share of meat in carcass sides of Swallow-Belly Mangalitsa was higher compared to values determined by Kralik and Petričević (2001, 28.8\%), Petrović et al. (2009 and 2010, 27.81\%) and Petrović et al. $(2011,31.97 \%)$ and were in concordance with results obtained by Egerszegi et al.(2003).

In MLD of fatteners reared in closed system (Table 4), was established higher share of water $(+2.22 \%, p=0.0069)$ and lower share of total fats $(-2.64 \%$, $p=0.0081$ ) compared to animals from open system of housing. Statistically significantly higher content of ash was established $(+0.07 \%, p=0.0392)$ in MLD of fatteners reared in closed system of housing. 
Average $\mathrm{pH}_{1}$ values show that both groups of fatteners had meat of normal quality with higher variability of traits in animals reared in closed system, so that the difference of 0.28 wasn't statistically significant $(p=0.0659)$.

Table 4. The influence of housing system (SBF) and weight of warm carcass sides (WWC) on varying of chemical composition and $\mathbf{p H}_{\mathbf{1}}$ value of musculus longissimus dorsi

\begin{tabular}{|l|c|c|c|}
\hline \multirow{2}{*}{ Trait } & \multicolumn{2}{|c|}{ Housing system (SBF), LS Mean \pm SE } & \multirow{2}{*}{ p -value } \\
\cline { 2 - 3 } & Open (SO) & closed (SI) & \\
\hline Water, \% & $68.49 \pm 0.41^{\mathrm{a}}$ & $70.71 \pm 0.48^{\mathrm{b}}$ & 0.0069 \\
\hline Protein,\% & $22.16 \pm 0.38$ & $22.49 \pm 0.49$ & 0.5940 \\
\hline Total fat,\% & $8.09 \pm 0.51^{\mathrm{a}}$ & $5.45 \pm 0.61^{\mathrm{b}}$ & 0.0081 \\
\hline Ash, \% & $1.02 \pm 0.02^{\mathrm{A}}$ & $1.09 \pm 0.02^{\mathrm{B}}$ & 0.0392 \\
\hline $\mathrm{pH}_{1}$ & $6.04 \pm 0.10$ & $6.32 \pm 0.32$ & 0.0659 \\
\hline
\end{tabular}

A,B significant at level $\mathrm{p}<0.05$

a,b significant at level $\mathrm{p}<0.01$

Fatteners reared in open system had statistically significantly $(\mathrm{p}<0.01)$ less water, more total fats/lipids $(\mathrm{p}<0.01)$ and statistically significantly $(\mathrm{p}<0.05)$ less ash in musculus longissimus dorsi compared to fatteners in closed system. Obtained results are in accordance with research carried out by Butko et al. (2007) who established less water and more fats/lipids in MLD of Black Slavonian pig reared in open system. Also, mentioned authors established no statistically significant difference in $\mathrm{pH}_{1}$ values between two housing systems. In our research, mean $\mathrm{pH}_{1}$ values were lower than values obtained in the study by Butko et al. (2007; 6.60 and 6.70).

High protein content in mixtures used in feeding of fattening pigs had impact on increase of protein content $(21.47 \%$ compared to $20.93 \%)$ and water content $(70.62 \%$ compared to $65.70 \%)$ and decrease of share of fats/lipids $(6.89 \%$ compared to 12.34\%) in MLD of Black Slavonian breed (Senčić et al.,2011). In our study, fatteners reared in closed system were fed two complete mixtures containing more proteins (15\% and 13\%) than mixtures used in the research by Sencić et al. (2011; 14\% and $12 \%)$, so that the protein content in MLD was higher $(22.49 \%$ compared to $21.47 \%$ ). Castrates of Swallow-Belly Mangalitsa reared in open system in present study had higher protein content in MLD $(22.16 \%)$ than animals of same genotype and housing system in the research by Parunović et al. (2012). Housing animals of same genotype (Italian local breed) in open system and feeding complete commercial mixtures increases the content of intramuscular and intermuscular fats, but also proteins (23,5\% compared to $22,8 \%$ ) compared to closed system (Pugliese et al., 2005).

Results of fattening of Large Yorkshire pigs housed in semi-open system, but slaughtered at different body weights (125.22 and $108.52 \mathrm{~kg}$ ) show that the composition of individual carcass side parts changes, but the meat contents in 
carcasses was almost equal in booth groups (47.04\% and 47.20\%) (Kuzelov et al., 2011).

\section{Conclusion}

Obtained results in the present study show that animals reared in open system had statistically significantly thicker fat measured on lower back (BFR I) compared to animals reared from closed system. Total weight of all four individual carcass side parts and weight of relevant depended on the weight of warm carcass sides, but not on housing system.

In MLD of fatteners kept in closed system higher water content was established $(p=0.0069)$, lower content of total fats/lipids $(p=0.0081)$ and higher ash content compared to animals reared in the open housing system $(p=0.0392)$.

Acknowledgment: Research was financed by the Ministry of Education and Science Republic of Serbia, project TR 31081.

\section{Sastav polutki i kvalitet mesa lasaste mangulice gajene u dva sistema}

M. Petrović, ¿̌. Radović, N.Parunović, D. Radojković, R. Savić

\section{Rezime}

Cilj ovog rada je bio da se utvrdi sastav polutki i kvalitet mesa tovljenika (muška kastrirana grla) lasaste mangulice gajenih u dva sistema držanja i ishrane.

Ustanovljene su statistički značajne razlike srednjih vrednosti samo debljine slanine izmerene na jednoj poziciji na krstima (BFR I) izmedju tovljenika gajenih u otvorenom i zatvorenom sistemu. Sve linearne mere toplih polutki, osim BFR II i BFR III, zavisile su od mase toplih polutki odnosno mase tovljenika pri klanju. Ukupna masa sva četiri pojedinačna dela polutke i masa mišićnog tkiva u njima, zavisila je od mase toplih polutki ali ne i sistema držanja.

U polutkama tovljenika bilo je prosečno $35,64 \pm 4,39 \%$ mišićnog tkiva (Stvarni MTP). Sadržaj mesa u polutkama prema PRAVILNIKU (1985) (Procenjeni MTP) za masne svinje iznosio je 29,67 $\pm 1,27 \%$.

U MLD tovljenika držanih u zatvorenom sistemu utvrdjen je veći sadržaj vode $(+2,22 \%, p=0,0069)$, manji ukupnih masti $(-2,64 \%, p=0,0081)$ i veći sadržaj pepela $(+0,07 \%, p=0,0392)$ nego kod grla iz otvorenog sistema držanja. 


\section{References}

AOAC (1990): Official methods of analysis of the association of official analytical chemists (15th ed.). Association of Official Analytical Chemists, Washington, DC. BUTKO D., SENČIĆ Đ., ANTUNOVIĆ Z., ŠPERANDA M., STEINER Z. (2007): Pork carcass composition and the meat quality of the black slavonian pig the endangered breeds in the indoor and outdoor keeping system. Poljoprivreda, 13, 1, 167-171.

COMISSION REGULATION (EC) No 3127/94 of 10 December 2008 laying down detailed rules on the implementation of the Community scales for the classification of beef, pig and sheep carcasses and the reporting of prices thereof. Journal of European Union L 337, 16/12/2008, 337/23.

EGERSZEGI I., RÁTKY J., SOLTI L., BRÜSSOW K-P. (2003): Mangalica - an indigenous swine breed from Hungary (Review). Arch. Tierz., Dummerstorf, 46, 3, 245-256.

HOLLÓ G., SEREGI J., ENDER K., NÜRNBERG K., WEGNER J., SEEGER J., HOLLÓ I., REPA I. (2003): A mangalica sertések húsminőségének, valamint az izom és a szalonna zsírsavösszetételének vizsgálata. Acta Agraria Kaposvariensis, 7, 2, 19-32.

KRALIK, G., PETRIČEVIĆ, A. (2001): Production traits of Black Slavonian pig. Proceedings: Biological diversity in animal production of Republic of Croatia, Zagreb, Hrvatska, 115-122.

KUZELOV A., TASKOV N., ANGELKOVA T., ATANASOVA E., MLADENOV M. (2011): Impact of live weight on the quality of pigs halves and meat of the large white breed. Biotechnology in Animal Husbandry, 27, 3, 819824.

PARUNOVIĆ N., PETROVIĆ M., MATEKALO-SVERAK V., RADOJKOVIĆ D., VRANIĆ D., RADOVIĆ Č. (2012): Cholesterol and total fatty acid content in m. longissimus dorsi of Mangalitsa and Swedish Landrace. Acta Alimentaria, 41, 2, 161-171.

PETROVIĆ M., MIJATOVIĆ M., RADOVIĆ $\check{C}$., RADOJKOVIĆ D., PARUNOVIĆ N., STANIŠIĆ N. (2009): Genetic resources in pig breeding carcass and meat quality traits of Moravka and Mangalitsa breeds. $1^{\text {st }}$ Conference of the Balkan Network for the Animal Reproduction Biotechnology, Sofia, 14.

PETROVIĆ M., RADOVIĆ Č., MIJATOVIĆ M., RADOJKOVIĆ D., STANIŠIĆ N., PARUNOVIĆ N. (2011): The share of tissues in pig carcass sides of autochthonous breeds depending on the body mass and sex. Biotechnology in Animal Husbandry 27, 3, Book 1, 561-569.

PETROVIĆ M., RADOVIĆ Č., PARUNOVIĆ N., MIJATOVIĆ M., RADOJKOVIĆ D., ALEKSIĆ S., STANIŠIĆ N., POPOVAC M. (2010): Quality 
traits of carcass sides and meat of Moravka and Mangalitsa pig breeds. Biotechnology in Animal Husbandry, 26, 1-2, 21 - 27.

PRAVILNIK O KVALITETU ZAKLANIH SVINJA I KATEGORIZACIJI SVINJSKOG MESA (1985): Službeni list SFRJ, br. 2, 20-30.

PUGLIESE C., BOZZI R., CAMPODONI G., ACCIAIOLI A., FRANCI O., GANDINI G. (2005): Performance of Cinta Senese pigs reared outdoors and indoors.: 1. Meat and subcutaneous fat characteristics. Meat Science, 69, 3, 459-464.

PUGLIESE, C., MADONIA, G., CHIOFALO, V., MARGIOTTA, S., ACCIAIOLI, A., GANDINI, G. (2003): Comparison of performance of Nero Sicilliano pigs reared indoors and outdoors. 1. Growth and carcass composition. Meat Science, 65:825-831.

SAS INST. INC (2002-2003): The SAS System for Windows, Cary, NC.

SENČIĆ Đ., SAMAC D., ANTUNOVIĆ Z., NOVOSELEC J., KLARIĆ I. (2011): Influence of crude protein level in forage mixtures on pig meat and carcass quality. Macedonian Journal of Animal Science, 1, 1, 89-93.

WALSTRA P., MERKUS G.S. M. (1996): Procedure for assessment of the lean meat percentage as a consequence of the new EU reference dissection method in pig carcass classification. Report ID-DLO 96.014, Lelystad, 1-22.

Received 16 February 2012; accepted for publication 25 May 2012 